University of Nebraska - Lincoln

DigitalCommons@University of Nebraska - Lincoln

Upland contribution of sediment and runoff during extreme drought: A study of the 1947-1956 drought in the Blackland Prairie, Texas

\author{
P.M. Allen \\ Baylor University, Peter_Allen@baylor.edu \\ R.D. Harmel \\ USDA-ARS Grassland
}

\author{
J.A. Dunbar \\ Baylor University \\ J. G. Arnold \\ USDA-ARS Grassland, jeff.arnold@ars.usda.gov
}

Follow this and additional works at: https://digitalcommons.unl.edu/usdaarsfacpub

Part of the Agricultural Science Commons

\begin{abstract}
Allen, P.M.; Harmel, R.D.; Dunbar, J.A.; and Arnold, J. G., "Upland contribution of sediment and runoff during extreme drought: A study of the 1947-1956 drought in the Blackland Prairie, Texas" (2011). Publications from USDA-ARS / UNL Faculty. 830.

https://digitalcommons.unl.edu/usdaarsfacpub/830
\end{abstract}

This Article is brought to you for free and open access by the U.S. Department of Agriculture: Agricultural Research Service, Lincoln, Nebraska at DigitalCommons@University of Nebraska - Lincoln. It has been accepted for inclusion in Publications from USDA-ARS / UNL Faculty by an authorized administrator of DigitalCommons@University of Nebraska - Lincoln. 


\title{
Upland contribution of sediment and runoff during extreme drought: A study of the 1947-1956 drought in the Blackland Prairie, Texas
}

\author{
P.M. Allen ${ }^{\mathrm{a}, *}$, R.D. Harmel ${ }^{\mathrm{b}}$, J.A. Dunbar ${ }^{\mathrm{a}}$, J.G. Arnold ${ }^{\mathrm{b}}$ \\ a Baylor University, Dept. of Geology, Waco, TX 76798, United States \\ ${ }^{\mathrm{b}}$ USDA-ARS Grassland, Soil and Water Research Laboratory, 808 E. Blackland Rd., Temple, TX 76502, United States
}

\section{A R T I C L E I N F O}

\section{Article history:}

Received 31 October 2010

Received in revised form 2 March 2011

Accepted 26 April 2011

Available online 3 July 2011

This manuscript was handled by

Konstantine P. Georgakakos, Editor-in-Chief,

with the assistance of Aiguo Dai,

Associate Editor

\section{Keywords:}

Drought

Sediment yield

Runoff

Midcontinent USA

\begin{abstract}
S U M M A R Y
The 1950s drought severely impacted a 1.1 million $\mathrm{km}^{2}$ area in the central US. This drought, along with the famous 1930s drought, was among the most severe of the 20th century for large areas and is the drought of record for water supply planning in Texas. At the USDA-ARS Riesel Watersheds during the drought, average annual rainfall was reduced $27 \%$, which produced $75 \%$ less runoff and $35 \%$ less sediment yield. Rainfall intensity during the drought was, however, typically greater than for the non-drought period. Based on long-term data from the Riesel Watersheds, the mean, 75th, 90th, and 95th percentile values of sediment yields on days with measureable soil loss were larger for the drought than non-drought periods. These results reflect the increase in rainfall intensity during the drought but more importantly the increased efficiency of drought rainfall to dislodge and transport sediment, which is attributed to the combined effects of reduced vegetative cover and increased soil erodibility. The potential for high sediment yields during drought periods illustrates the need to consider this landscape vulnerability in long-term planning and assessment and the importance of long-term monitoring to predict water supply impacts. This is especially evident in Texas, which is expected to experience a dramatic increase in population and water demand this century, with a corresponding decrease in reservoir storage capacity due to sedimentation.
\end{abstract}

(c) 2011 Elsevier B.V. All rights reserved.

\section{Introduction}

Droughts are one of the most devastating natural disasters in the US, impacting economics, society, and the environment. Droughts adversely impact water supply, water quality, crop production, rangeland productivity, power generation, and recreational activities as well as a number of other associated economic and social activities (Woodhouse and Overpeck, 1998). In the past 25 years in the US, more than 66 weather related events have caused greater than $\$ 500$ billion in damage (normalized to 2002 dollars; Lott and Ross, 2005). Eleven or 16\% of these have been major droughts and droughts have caused roughly $\$ 145$ billion in damages or $29 \%$ of the total weather related damages. The $1950 \mathrm{~s}$ drought in Texas wiped out about a fourth of the state's agriculture potential or about $\$ 27$ billion (2008 dollars) (Lowry, 1959; Stahle and Cleaveland, 1988).

An assessment of available proxy data suggests that the droughts of the 20th century have been characterized by short duration and moderate severity. Paleoclimatic records based on tree rings, archeological remains, lake sediment, and geomorphic data indicate that these more recent droughts have been exceeded

\footnotetext{
* Corresponding author.

E-mail address: Peter_Allen@baylor.edu (P.M. Allen).
}

several times in the past 2000 years by droughts of greater magnitude and duration. For example, as recently as the late 1500 s, a megadrought lasted 24 years from 1559 to 1582 and appeared to have greater spatial extent (continental scale) than current droughts (Stahle et al., 2007). Increased understanding of global climate dynamics and past analogs has begun to reveal that a classic La Nina pattern of ocean temperature in the Pacific was common to North American droughts (Seager, 2007). In assessing the potential magnitude, frequency, and impacts of future droughts, new models must take into account atmospheric and oceanic mechanisms which triggered these more severe paleo-droughts. In addition two other factors may complicate estimates of future drought effects: (1) increased productivity of agricultural land in more marginally arable terrain and (2) enhanced likelihood of global warming (Woodhouse and Overpeck, 1998).

\subsection{Drought impact assessment}

Eco-geomorphic effects such as erosion and sedimentation in response to droughts are typically studied through (1) short term (1-2 year) monitoring, (2) climate gradient inferences, or (3) model applications. Short term monitoring of drought conditions and sediment transport indicate that infrequent storm events during drought generate greater river sediment input than similar 
magnitude events under average moisture conditions, but that less sediment is likely to be transported through the system due to the reduced frequency of intermediate flows (Heritage and Van Niekerk, 1995; Kochel et al., 1997). Two-year drought studies in Spain indicated a reduction in soil water content below the wilting point, reduction in vegetative cover, reduction in the number of plants, changes in organic matter content and its concomitant effect on soil aggregates and permeability which supposes an increased potential for erosion (Ruiz-Sinoga and Martinez-Murillo, 2009). A problem with short-term sediment studies is that climate conditions may not be representative of long-term climate conditions nor do they take into account changes in vegetative and grazing patterns or general land use change.

A second procedure uses climate gradient inferences to compare climatic change impacts through application of space for time substitution (e.g., Langbein and Schumm, 1958; Wilson, 1973; Wolman and Gerson, 1978) or to evaluate landscape components across climatic gradients (e.g., Imeson and Lavee, 1998; Jaeger et al., 2010). While these studies are instructive for long-term differences in climate-induced sediment yield or stream erosion, they do not consider more abrupt drought-induced changes in vegetative cover caused by moisture stress and overgrazing. Care must also be exercised when interpolating watershed scale response to extreme climatic events. Lane et al. (1997) indicates that to properly evaluate sediment yield, landscape response should be considered relative to landscape position (i.e., plot to hillslope, and subwatershed to watershed scales) owing to different modes of erosion, transport, and sediment storage within these scaled landscapes.

Finally, simulation models are often used to evaluate of broadscale effects of climate change on erosion (e.g., Pruski and Nearing, 2002; Nearing et al., 2005; Tallaksen et al., 2009). Comparison of model predictions of drought effects is useful to assess the relevance of models in predicting physical response to climate change. Attempting to model climate extremes and change reveals the complex response and feedback mechanism whose impacts on erosion depend on both natural and anthropogenic shifts in land use (Nearing et al., 2004; Ward et al., 2009). Tallaksen et al. (2009) asserts that besides being useful in assessing the interactions and potential impacts at the outlet, many models can now look at spatial coverage in the definition of drought for different variables such as soil moisture, groundwater and lags in specific response functions such as soil moisture and runoff (Andreadis et al., 2005). While models allow inference, they are only as good as the calibration data. Trimble and Crosson (2000) indicates that much of the discussion of soil erosion and attempted rectification is based on modeling, often with little field-based evidence to verify the estimates. Thus, as noted by Heppner and Loague (2008), the need exists for increased long term monitoring data to better understand hydrologically-driven soil erosion and transport processes.

\subsection{Hydrology, erosion, and drought assessment in the Texas Blackland Prairie}

Sediment yield in the Texas Blackland Prairie ecoregion is highly variable (Coonrod et al., 1998). Based on suspended sediment yields at the 1.5 year recurrence interval (Simon et al., 2004), the Blackland Prairie ecoregion is a relatively high sediment producing region in Texas. Land use and management have a tremendous effect on erosion and sediment yields from upland areas (e.g., Smith et al., 1954; Wischmeier and Smith, 1965). Harmel et al. (2006) noted the monthly pattern of soil loss within the Blackland Prairie was similar to the temporal runoff pattern; however, interesting exceptions occurred due to temporally variable interactions between rainfall frequency and intensity, crop rotations, and land management. When the two major Texas Blackland
Prairie cropping systems were compared, the reduction in annual soil loss for small grains relative to row crop production was striking (Harmel et al., 2006). The reduced erosion rates are attributed to the increased soil cover provided by oats and wheat during both the fall and spring high runoff potential periods compared to corn or sorghum production, which provides soil coverage only in the spring.

Long-term, decadal sediment data coupled with climatic data on small upland basins are rare (Heppner and Loague, 2008). Long-term sediment data during the 1950s drought in southwestern US are only known to exist at the USDA-ARS Riesel Watersheds in Riesel, Texas (described subsequently). This site is located along the eastern edge of the 1950s drought based on Palmer Drought Severity Index (PDSI; which will be discussed later) and tree ring data. The 1950s drought (PDSI < -4.5) severely impacted a 1.1 million $\mathrm{km}^{2}$ area in the central US between Texas, Colorado, and Iowa. This drought, along with the 1930s drought, was among the most severe of the 20th century for large areas (Andreadis et al., 2005) and is the drought of record for water supply planning in Texas. In mid-east Texas, drought rainfall averaged 18\% less, temperatures were $0.7 \%$ warmer, annual gross evaporation was $8 \%$ greater, and humidity was $2 \%$ less than annual mean values (Lowry, 1959).

Recent work conducted at the geographic center of the $1950 \mathrm{~s}$ drought in Texas used detailed analyses of reservoir sedimentation in a series of rangeland watersheds (Dunbar et al., 2010). Coupling of reservoir sedimentation with precipitation records indicated that sediment yield per unit runoff during the drought was several orders of magnitude greater than in non-drought periods. The Riesel Watersheds, located only $150 \mathrm{~km}$ to the east, offer a unique opportunity to further examine the effects of drought on sediment yields as daily rainfall, runoff, and sediment data were collected from cropland and rangeland during drought and non-drought periods. Therefore, the objectives of this paper were to: (1) describe and establish rainfall, runoff, and sediment yield relationships for an upland watershed during drought conditions, and (2) contribute to filling the gap of climate change impact studies on soil erosion and runoff during a prolonged drought.

\section{Methods}

\subsection{History of the Riesel Watersheds}

The Blacklands Experimental Watershed, commonly called the Riesel Watersheds, was established in 1937. When the original Soil Conservation Service watersheds were established in Riesel, Texas, Coshocton, Ohio, and Hastings Nebraska, in the late 1930s (and transferred to ARS in 1953), little information was available on the impacts of land use and management on runoff, soil loss, and water quality from small agricultural watersheds (Harmel et al., 2007). The Riesel Watersheds, along with the North Appalachian Experimental Watershed near Coshocton, Ohio, are the only two original watersheds that have remained in operation since the beginning of the ARS watershed network (Harmel et al., 2007). This national network, which was expanded in the 1950s and again in recent years, has for decades been an important source of regional research and data on hydrology and sediment transport. Its longterm sites with continuous records have proven valuable for studies designed to identify trends or changes caused by climate shift or other factors and are necessary to determine the influence of infrequent extreme events, such as floods (Edwards and Owens, 1991; Pierson et al., 2001; Nichols et al., 2002; Harmel et al., 2003; Bonta, 2004), especially since few private, local, and state entities have the resources or stated responsibility to conduct long-term integrated research and monitoring (Slaughter and Richardson, 2000). Much of the early research at Riesel focused 
on quantification of a conservation management system's ability with terraces, grassed waterways, contour farming - to reduce peak flow rates and soil erosion (e.g., Baird, 1948, 1950, 1964), and erosion studies have continued through the years (e.g., Chichester and Richardson, 1992; Richardson and King, 1995). The Riesel Watersheds were designed to provide field-scale, realworld information; therefore, the facility has been managed as a typical farm and ranch operation since its inception.

\subsection{Legacy database}

Continuous data collection and research efforts at the Riesel Watersheds since the 1930s have produced a massive legacy database containing runoff, precipitation, sediment, and land management data (www.ars.usda.gov/spa/hydro-data). The original infrastructure at Riesel included multiple watersheds and rain gauges on private land in the Brushy Creek watershed and on smaller sites on land purchased by the USDA. Currently, 17 water monitoring stations and 15 rain gauges measure rainfall, runoff, and water quality on native prairie, improved pasture, and cultivated cropland sites. For a more detailed description of historical data collection at Riesel, see Harmel et al. (2007).

\subsection{Site description}

The Riesel Watersheds, which contain 340 ha of government owned land in the 2372 ha Brushy Creek watershed, is located in the heart of the 4.45 million ha Texas Blackland Prairies ecoregion (Fig. 1). Present day agricultural land use in this ecoregion consists of cattle production on pasture and rangeland, and corn, wheat, grain sorghum, and oat production under a wide range of tillage and management operations. The ecoregion also contains the major metropolitan areas of Dallas-Fort Worth, Austin, and San Antonio. Long, hot summers and short, mild winters characterize the climate. Most of the annual precipitation (approx. $890 \mathrm{~mm}$; Harmel et al., 2003) occurs with the passage of Canadian continental and Pacific maritime fronts, but convective thunderstorms and occasional hurricanes can contribute intense rainfall.

Houston Black clay soils (fine, smectitic, thermic, udic Haplustert), recognized throughout the world as the classic Vertisol, dominate the watershed site. These highly expansive clays, which have a typical particle size distribution of $17 \%$ sand, $28 \%$ silt, and $55 \%$ clay, shrink and swell considerably with changes in moisture content. This soil series consists of very deep, moderately well-drained soils formed from weakly consolidated calcareous clays and marls and generally occurs on 1-3\% slopes in upland areas. These soils

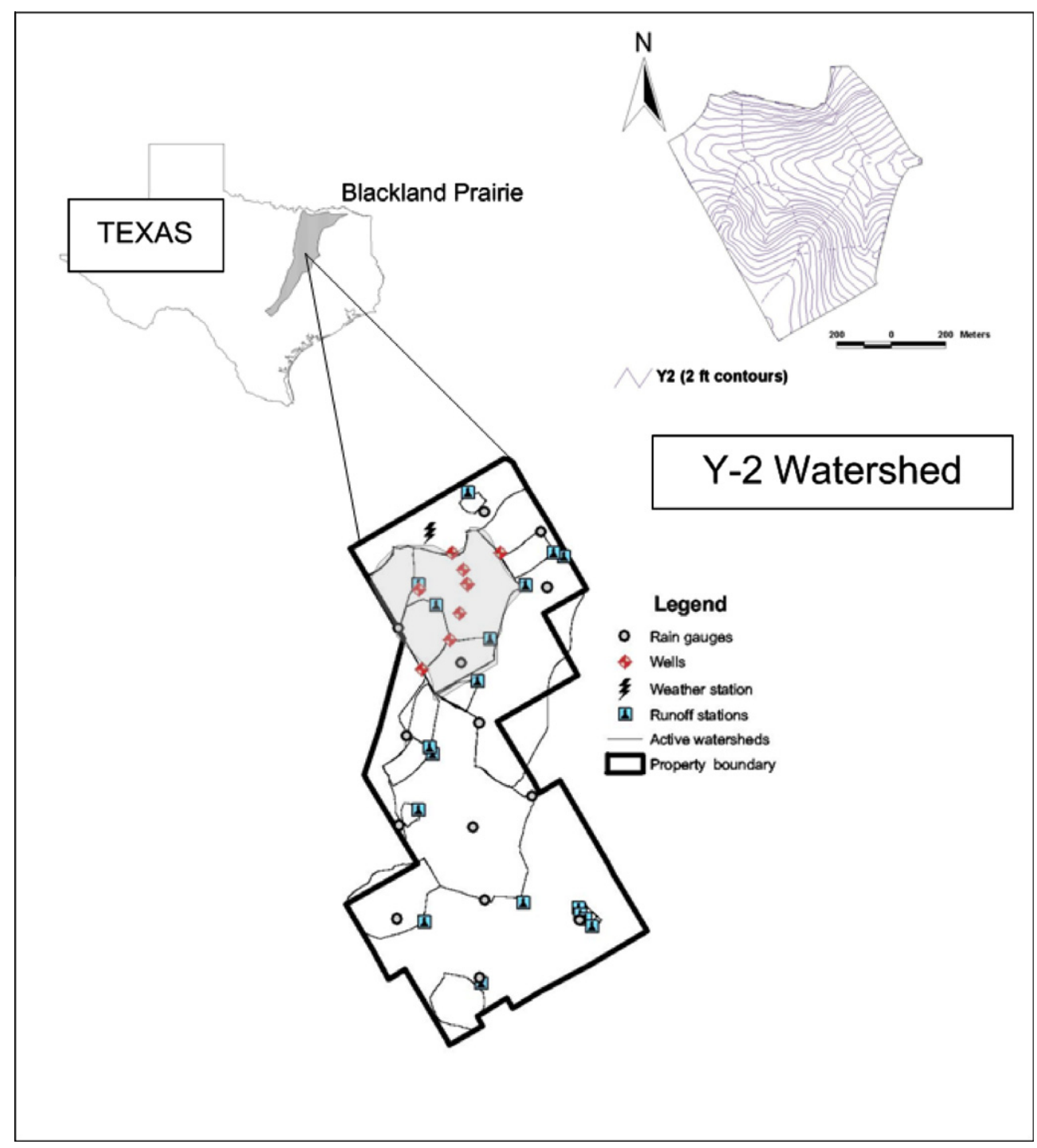

Fig. 1. Active experimental watersheds and rain gauges at the USDA-ARS Riesel Watersheds (Harmel et al., 2006). 
Table 1

Approximate dates and land use percentages for watershed Y2.

\begin{tabular}{|c|c|c|c|c|}
\hline Period & Cultivated (\%) & Pasture (\%) & Cultivation practices & Comments \\
\hline 1937-1942 & 91 & 9 & Straight rows, no terraces & No land use alteration \\
\hline 1943-1947 & 72 & 28 & Contour cultivation, terraces, grassed waterways & Incremental conversion of cultivated land to pasture \\
\hline $1948-1975$ & 65 & 35 & Contour cultivation, terraces, grassed waterways & $\sim 9$ ac converted to pasture at some time during period \\
\hline 1976-Present & 54 & 46 & Contour cultivation, terraces, grassed waterways & $\sim 12$ ac converted to pasture in 1975 \\
\hline
\end{tabular}

are very slowly permeable when wet (approximate saturated hydraulic conductivity of $1.5 \mathrm{~mm} / \mathrm{h}$ ); however, preferential flow associated with soil cracks contributes to high infiltration rates when the soil is dry (Allen et al., 2005).

The Y2 watershed at Riesel (Fig. 1) was selected for the present evaluation of the upland contribution of sediment under drought conditions because of its long-term data in a small, upland setting. A basic history of land use and management of Y2 appears in Table 1. The watershed has averaged $70 \%$ cultivated and 30\% pasture over a 73 year period. Data at the small watershed scale are valuable for evaluating runoff and sediment transport because data collected at larger scales are often influenced by dams, channel processes, differing land uses, and precipitation variability, which alter flow routing and confound interpretation of management effects.

\subsection{Data analysis}

Rainfall intensity was calculated for the drought period (19481953) and non-drought period (1962-2008) for years with measured sediment yield data. Intensity $(\mathrm{mm} / \mathrm{h})$ was calculated from subdaily data for rain gauge $75 \mathrm{~A}$ both for all days with rainfall and for days with measured sediment yield.

The antecedent precipitation index (API) was also calculated by the method of Kohler and Linsley (1951) to estimate the soil moisture status prior to rainfall/runoff events.

$\mathrm{API}=\sum P_{t} k^{-t}$

where $t$ is the number of antecedent days, $k$ is the decay constant $(0.9)$, and $P$ is the precipitation during day $t$. Time variant API was obtained after methods of Hong et al. (2007) where the numerator is API, and the denominator is a normalizing operator with two components, average daily precipitation and $\sum k^{-1}$ series.

The PDSI, a meteorological drought index based on precipitation, temperature, and soil available water capacity commonly applied in Texas, was also calculated to provide standardized measurements of moisture conditions for regional and temporal comparisons. The index varies roughly between \pm 6 with mild droughts beginning at -1.0 and extreme droughts at -4.0 or less (National Climatic Data Center, 2010).

The erosion index and regression analysis were used to compare sediment yields from drought and non-drought periods. With the erosion index method, the annual sediment/runoff ratio for the drought was divided by the total ( 58 year) sediment/runoff ratio (Giakoumakis and Tsakiris, 1997). Linear and non-linear regression was used to evaluate potential differences in relationships between runoff and sediment yield for the drought and non-drought periods.

\section{Results and discussion}

\subsection{Rainfall}

Rainfall characteristics at Riesel have been summarized by Harmel et al. (2003). Mean annual rainfall for four continuously active gages ranged from 884 to $898 \mathrm{~mm}$ for 1939-1999. Rainfall is weakly bimodal with about $33 \%$ of the annual rainfall produced in spring (April through June) and about 26\% produced during the fall (October through December). Winter and summer months are relatively dry making up the remaining $41 \%$. Average monthly rainfall varies from $115 \mathrm{~mm}$ in May to less than $50 \mathrm{~mm}$ in July. Rainfall variability exhibited a seasonal pattern, which mirrored mean rainfall amount with the wetter months exhibiting greater variability. For the Y2 watershed, annual rainfall measured for the period 1939-2002 averaged $907 \mathrm{~mm}$ with a standard deviation of $234 \mathrm{~mm}$ (Harmel et al., 2006).

Annual precipitation during the drought averaged 27\% less than during the non-drought period (Fig. 2). Seven years of the 10 year drought produced annual precipitation below the meteorological criterion of $30 \%$ less than the mean annual precipitation as defined by the Texas Water Development Board (TWDB, 2007). On average, measureable rain occurred on 66 days each year in the drought compared to 96 days per year in non-drought period from 1941 to 2008. On days with rain, the average daily rainfall was 10.0 $\mathrm{mm}$ during the drought and non-drought periods, but the median was greater for the drought (4.6 mm compared to $3.3 \mathrm{~mm}$ for the non-drought period (Fig. 3). During the drought, 17 days per year had more than $12.7 \mathrm{~mm}$ of rain on average and 8 days per year had more than $25.4 \mathrm{~mm}$. During the non-drought period, 24 days per year had rain of more than $12.7 \mathrm{~mm}$ and 12 days per year had more than $25.4 \mathrm{~mm}$. The largest daily rainfall during the drought was $83.6 \mathrm{~mm}$ compared to 190.8 for the non-drought period.

Although rainfall amounts at Y2 were obviously lower during the drought, rainfall was typically more intense. When days with rain were compared for drought and non-drought periods (Fig. 4a), average event intensity was larger for the drought $(4.7 \mathrm{~mm} / \mathrm{h})$ than for the non-drought period $(3.5 \mathrm{~mm} / \mathrm{h})$, but median intensity was lower (drought $1.0 \mathrm{~mm} / \mathrm{h}$, non-drought $1.7 \mathrm{~mm} /$ h). When intensity was compared for days with measured sediment loss (Fig. 4b), average and median values were larger for the drought (avg. $=9.0 \mathrm{~mm} / \mathrm{h}$, median $=6.5 \mathrm{~mm} / \mathrm{h}$ ) than for the non-drought period (avg. $=5.3 \mathrm{~mm} / \mathrm{h}$, median $=3.4 \mathrm{~mm} / \mathrm{h}$ ).

\subsection{Palmer Drought Severity Index (PDSI) and Southern Oscillation Index (SOI)}

The PDSI based on NOAA reconstructions for Riesel, within the spatial region and temporal period strongly impacted by the drought, is shown annually with rainfall (Fig. 5). According to the index, the drought began with an incipient dry spell in 1948 $(\mathrm{PDSI}=-0.20)$ and then a moderate drought in 1951 (PDSI $=$ -2.02 ) and severe to extreme drought from 1952 to 1956 (PDSI = -3.02 to -4.47 ) with only 1954 being less severe, and classed as a moderate drought (PDSI -2.19 ). The mean PDSI for the drought (1947-1956) was -1.35.

The Southern Oscillation Index (SOI) indicates general La Nina trends for the drought period in Texas. The SOI, which is calculated from seasonal air pressure differences between Tahiti and Darwin, ranges from -35 to +35 with the values above 0.0 relating to La Nina episodes and values below this to El Nino. In general, mean SOI for the period of drought was 2.4 with higher values in 1950 (14.9), 1955 (10.8), and 1956 (10.3). The severity of drought is influenced by winds, temperatures, humidity and relationships 


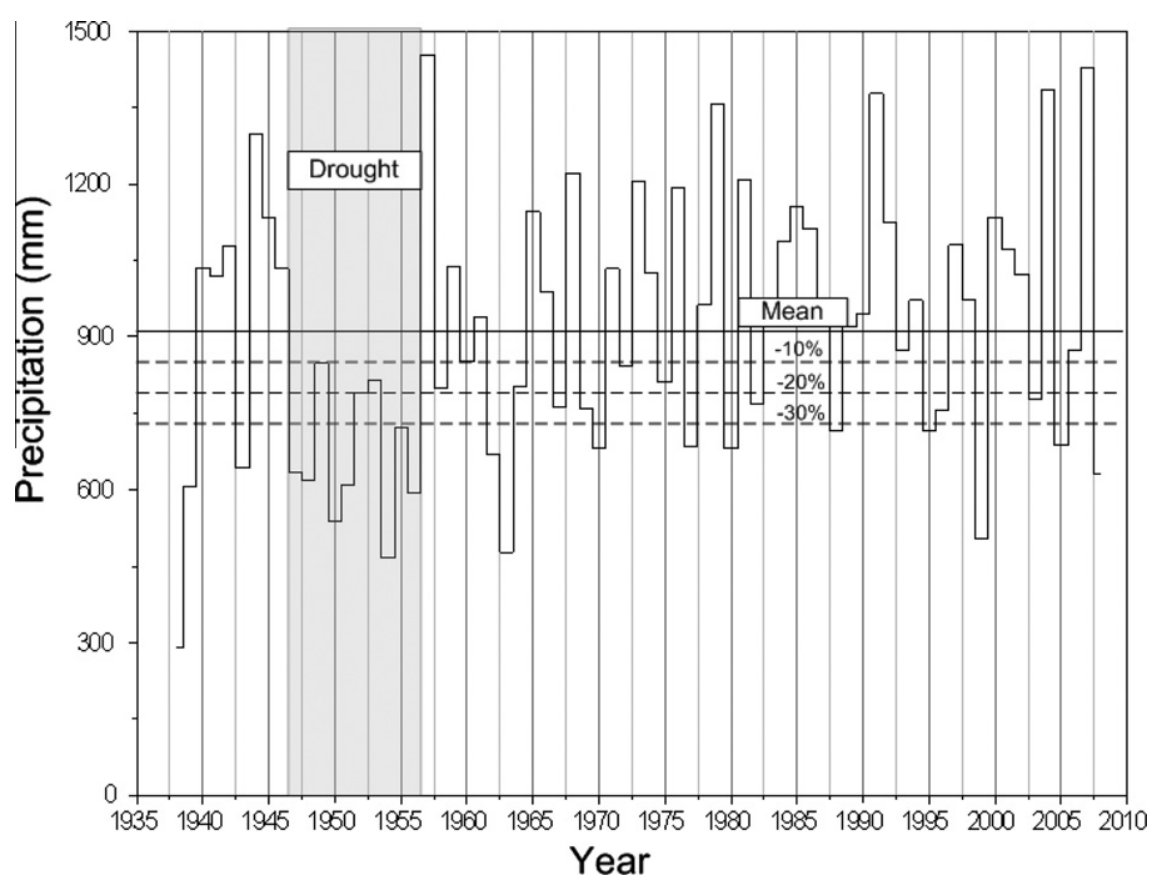

Fig. 2. Annual precipitation measured at the USDA-ARS Riesel Watersheds (1938-2008).

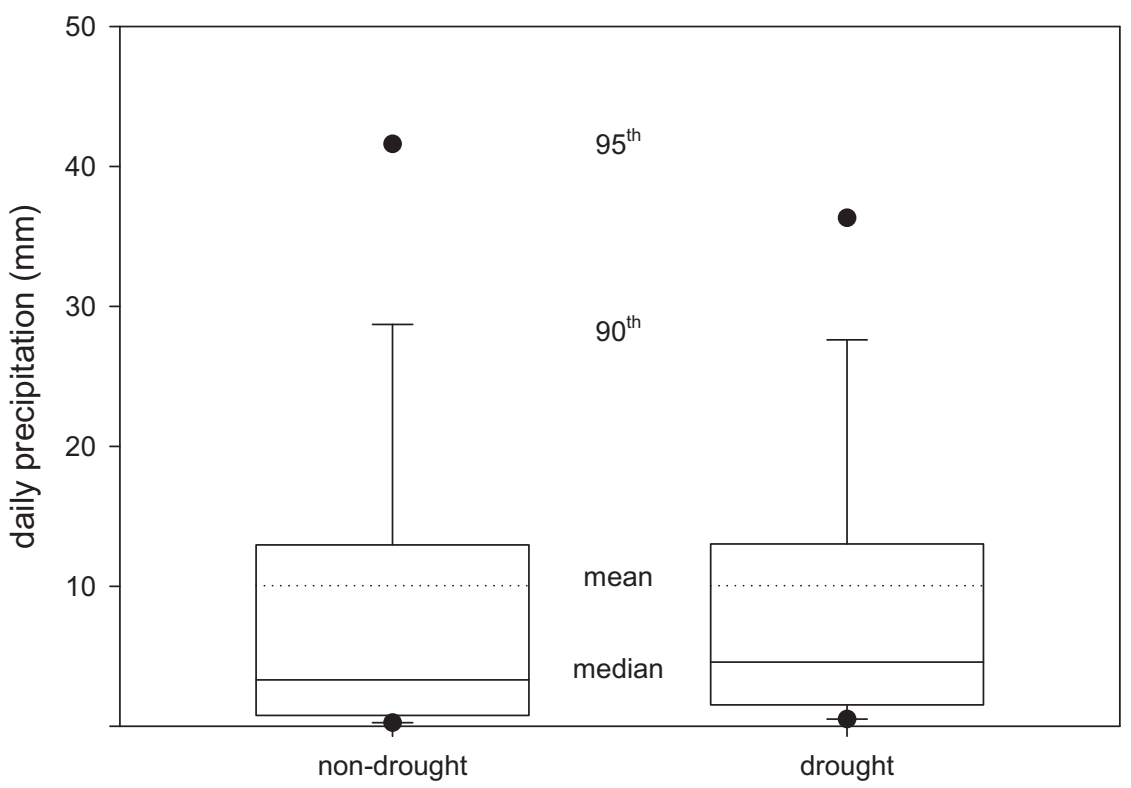

Fig. 3. Distribution of daily rainfall, on days with rain, during drought and non-drought periods.

with large scale global climate trends. The ENSO or El Nino Southern Oscillation is the result of cyclic warming and cooling of surface ocean temperatures in the central and eastern Pacific. It has been found that the more intense the La Nina or cooling cycle of the Pacific, the drier and hotter conditions become in the southwest, northern plains, and southeast coast. Links between Pacific sea surface temperature (SST) have been studied in detail by Barlow et al. (2001) with reference to drought. The authors analyzed three SST's and noted that they appear to play a significant role in long term US drought events. The authors go onto state that while the analysis identifies important links between causative structures in drought climate events, they advise caution in using such results for prediction in that their best case simulations would probably not explain more than $25 \%$ of the variance for most regions. Other work cited by Clark et al. (2002) reinforces the complexity in drought prediction in that there is strong evidence that the state of both oceans (Pacific and Atlantic) directly or indirectly lead to drought in the Great Plains. The SOI is given here solely to indicate this parameter which is often linked with climate variability and not to infer its use in drought prediction.

\subsection{Runoff and sediment}

Allen et al. (2005) described an annual cycle of cracking, soil moisture increases, soil sealing, and subsequent runoff at Riesel with four soil water phases (dry, field capacity, saturated, and transition). These phases drive the runoff variability that occurs in the Texas Blackland Prairie ecoregion (Allen et al., 2005; Harmel et al., 

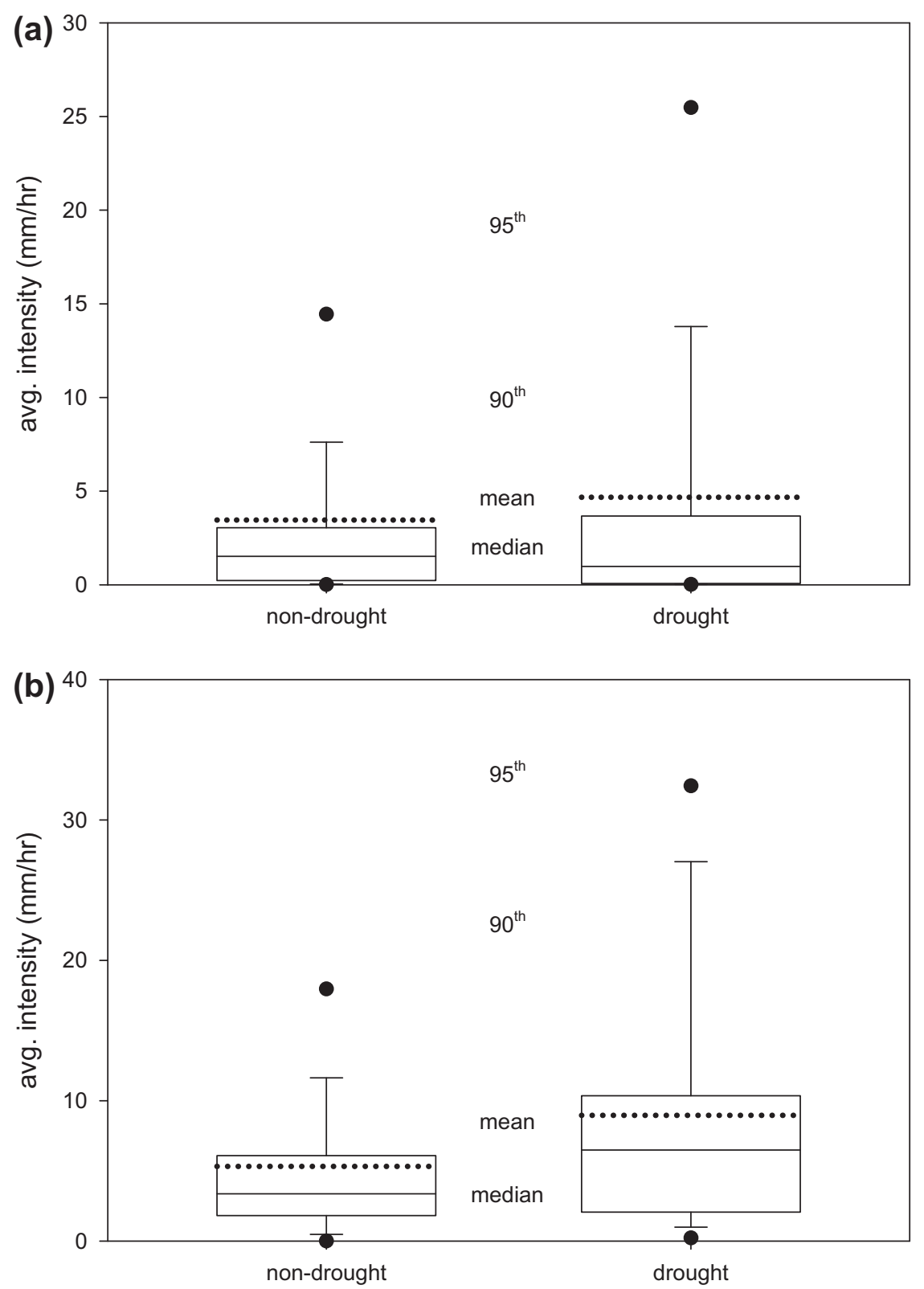

Fig. 4. Distribution of rainfall intensity during drought and non-drought periods: (a) for days with rain, (b) for days with measured sediment loss.

2006). As shown in Fig. 6, both the mean and median runoff on days with runoff for the drought period $(2.6 \mathrm{~mm}, 0.11 \mathrm{~mm})$ were greater than for the non-drought period $(2.2 \mathrm{~mm}, 0.06 \mathrm{~m})$. The maximum daily runoff during the drought was $33.0 \mathrm{~mm}$ compared to $157.7 \mathrm{~mm}$ in the non-drought period, although the 95th percentile runoff value was much less for the non-drought period.

As shown in Table 2, average annual soil loss for watershed Y2 during the drought $(558 \mathrm{~kg} / \mathrm{ha}$ ) was only $65 \%$ of that during the non-drought period $(857 \mathrm{~kg} / \mathrm{ha})$. The distribution of sediment yield during days with measureable soil loss shows that the mean, 75th, 90th, and 95th percentiles values of daily sediment loss were larger for the drought period, although the median was larger for the non-drought period (Fig. 7).

According to the erosion index, drought sediment yield per unit runoff $(\mathrm{kg} / \mathrm{ha} / \mathrm{mm})$ was 2.5 times higher than the long-term average (Table 2), but the pre-drought (1945-1946) erosion index was also 2.5 times higher. As shown in Table 1, the land use and management alterations during 1943-1947, which dramatically reduced erosion relative to pre-1943 conditions (Baird, 1948,
1964), were not completed until 1947. Thus, the best comparison of sediment yield per unit runoff during the drought is with the entire set of non-drought data (1945-1946, 1960-2008) to minimize the effects of land use change (Table 1). Based on that comparison, the sediment yield per unit runoff was more than 2.5 times greater for the drought period, which clearly indicates the drought impact. To verify this conclusion, an adjacent watershed (W1) with more data available prior to and within the drought was examined. The mean and median sediment yield per unit runoff were both greater for the drought years (1947-1953) than in the pre-drought years (1939-1946), which supports the conclusion of substantial drought impact.

Regression analyses indicated that sediment yield and runoff are more highly correlated in the drought $\left(R^{2}=0.97\right)$ than in the non-drought period $\left(R^{2}=0.34\right)$ (Fig. 8). The runoff-sediment yield relationship for the drought appears to fall along the upper bound of the scattered runoff-sediment yield points for the entire period of record at Riesel. In contrast, rainfall intensity and sediment yield were not well correlated (Fig. 9). $R^{2}$ values were $<0.07$, and no clear 


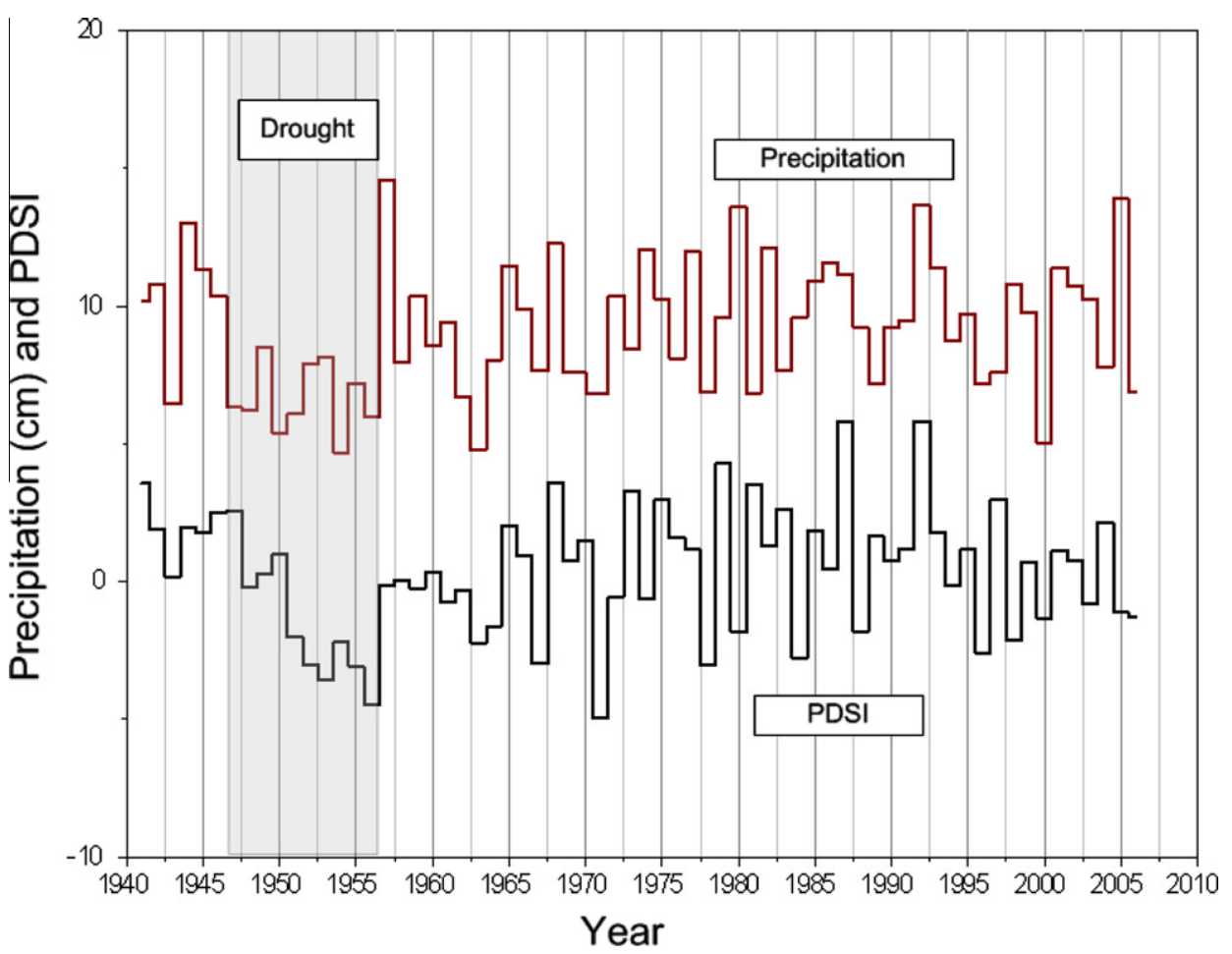

Fig. 5. PDSI and precipitation at the Riesel Watersheds.

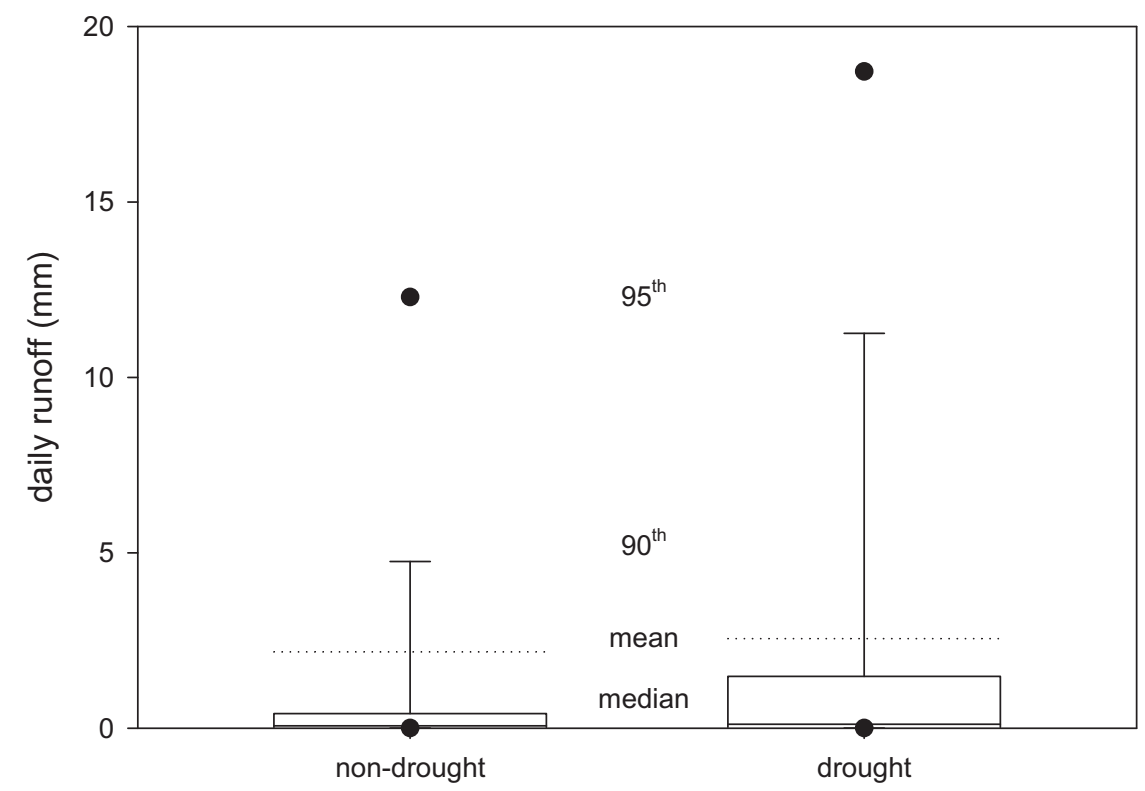

Fig. 6. Distribution of daily runoff events during drought and non-drought periods.

differences in the relationship between rainfall intensity and sediment yield were observed for the drought and non-drought periods. So while the drought reduced average annual rainfall by $27 \%$, runoff by $75 \%$, and total soil loss by $35 \%$, this did not translate into a corresponding reduction in per event soil erosion. Due to the increase in rainfall intensity during the drought and more importantly due to the increase in efficiency of drought storms to dislodge and transport material (Prosser et al., 2000), drought storms which produced runoff were more efficient in sediment detachment and transport. The mechanisms for runoff production in the smectitic clays of the Blackland Prairie are complicated
(Allen et al., 2005; Arnold et al., 2005) and relate to at least three major variables which control crack volume and surface detention storage: (1) antecedent soil moisture status, which is a product of soil depth, evaporative energy, and land use, (2) rainfall volume and rainfall intensity, and (3) land use. These variables were used to successfully predict runoff at Riesel for recent storms (Arnold et al., 2005), but similar predition for the sediment production during prolonged droughts would require accurate prediction of the extreme crack volumes and their impacts on runoff, soil detachment, and transport. In such extreme drought, temporary storage (in excess of $78 \mathrm{~mm}$ based on Arnold et al., 2005) would need to 
Table 2

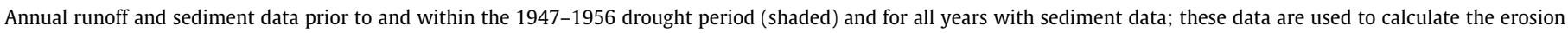
index.

\begin{tabular}{|c|c|c|c|c|}
\hline Year & Runoff (mm) & Sediment yield (kg/ha) & Yield per unit runoff $(\mathrm{kg} / \mathrm{ha} / \mathrm{mm})$ & Erosion index \\
\hline 1945 & 325.6 & 2936 & 9.0 & 1.8 \\
\hline 1946 & 196.9 & 3790 & 19.2 & 3.8 \\
\hline Pre-drought avg. & 261.3 & 3363 & 12.9 & 2.5 \\
\hline 1947 & 121.9 & 675 & 5.5 & 1.1 \\
\hline 1948 & 46.7 & 870 & 18.6 & 3.7 \\
\hline 1949 & 26.7 & 564 & 21.1 & 4.2 \\
\hline 1950 & 23.1 & 514 & 22.3 & 4.4 \\
\hline 1951 & 0.0 & 0.0 & - & - \\
\hline 1952 & 32.8 & 362 & 11.0 & 2.2 \\
\hline 1953 & 59.9 & 922 & 15.4 & 3.0 \\
\hline 1954 & - & - & - & - \\
\hline 1955 & - & - & - & - \\
\hline 1956 & - & - & - & - \\
\hline Drought avg. & 44.4 & 558 & 12.6 & 2.5 \\
\hline Non-drought (1945-1946, 1960-2008) avg. & 177.9 & 857 & 4.8 & 0.9 \\
\hline All years $(1945-1953,1960-2008)$ avg. & 161.8 & 821 & 5.1 & - \\
\hline
\end{tabular}

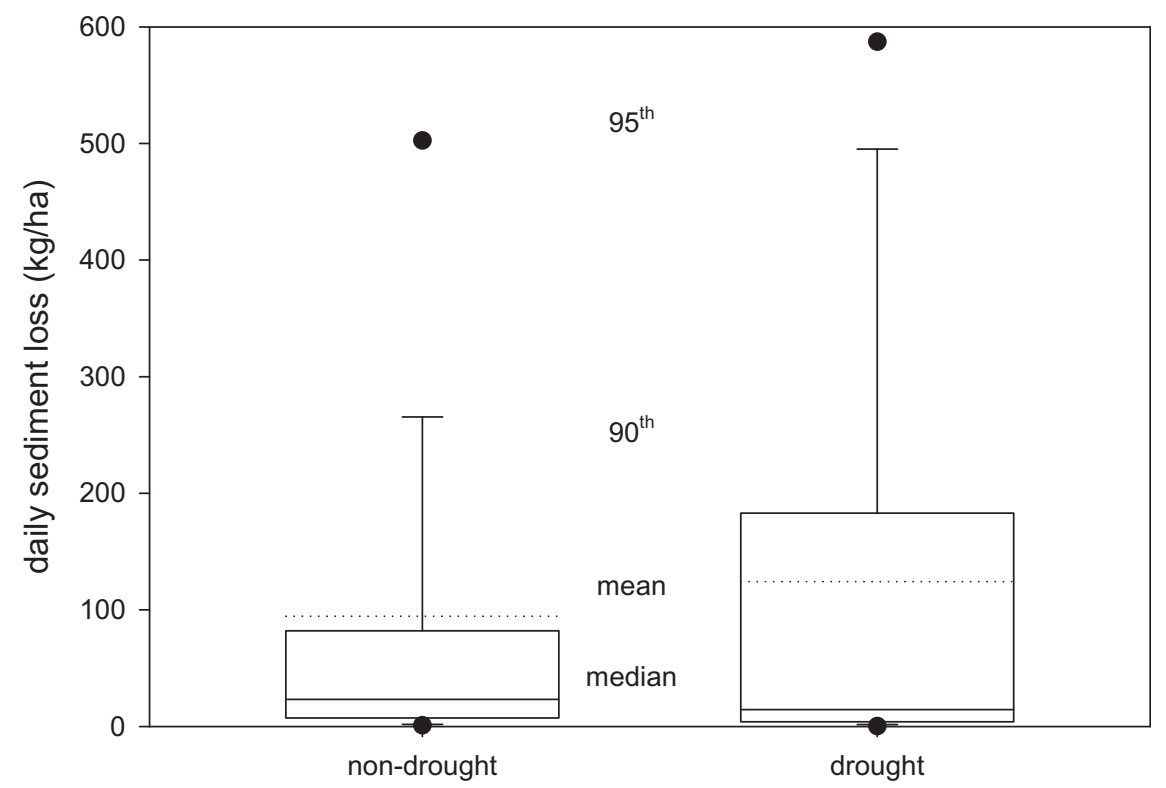

Fig. 7. Distribution of daily sediment loss during drought and non-drought periods (sediment loss data only available for 1948-1953).

be overcome to generate runoff, thus rainfall intensity alone would not account for the variation in sediment yield. Once this storage is diminished by precipitation and soil swelling, soil loss should be better related to storm intensity and duration.

This increase in efficiency of runoff to produce sediment during the drought appears to result from the combined effects of less vegetative cover and drier antecedent conditions. Dunbar et al. (2010) clearly show that the loss of cover during drought dramatically increases soil erosion (as evidenced by sediment in floodwater reservoirs). Soil moisture prior to rainfall events, was computed using a 5 day mean antecedent precipitation index after Hong et al. (2007). The API for the drought was 0.0715 while that for nondrought period was 0.1033 or about $30 \%$ lower. This indicates that conditions preceding a drought storm event were drier than nondrought events.

During the drought, with reduced rainfall, soil cover, and API values, runoff at Riesel was more effective in eroding and transporting sediment. A factor which contributes to increased runoff effectiveness during drier conditions appears to be complex subaerial processes in the soil (Freebairn et al., 1996). Numerous studies have shown that changes of soil erodibility during drying cycles need to be included in assessing erosion rates and soil erodibility (Martinez-Mena et al., 1998; Bryan, 2000; Kuhn and Bryan, 2004; Knapen et al., 2007). For example, Kuhn and Bryan (2004) noted a twofold increase in erosion during dry (low API) conditions for clay textured soils. In general, dessication cracking can influence rill network development, piping, and perhaps the tendency of the soil to form aggregates and a more granular structure which can enhance entrainment. Zhang and Miller (1993) found that drying caused shrinkage and seal disintegration leading to easily eroded material in the subsequent storm for swelling clays in Georgia, US. Bryan (1996) indicates clay mineralogy also affects the intensity of inter-storm cracking creating new pathways for increased infiltration and promotes piping and rill incision. Ben-Hur et al. (1985) indicates that prolonged inter-storm drying promoted seal breakdown and produced a more permeable surface layer more vulnerable to rainfall impact and erosion.

The soils at Riesel during the drought presumably had increased surface crack frequency and crack volume (Arnold et al., 2005) as well as lower organic matter content due to combined effects of grazing and reduced vegetative productivity, especially in grasses (Clark et al., 2002; Diodato, 2006). This combination enhances soil 


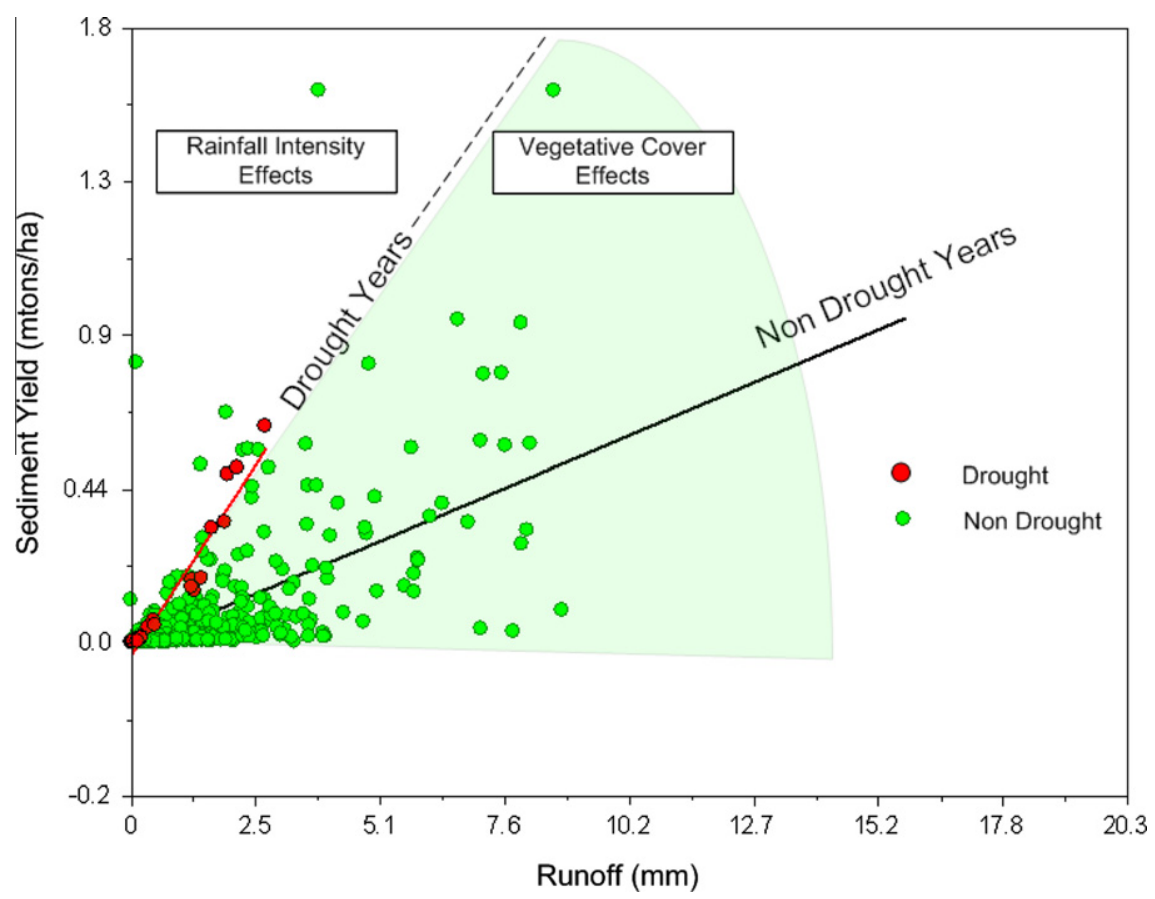

Fig. 8. Drought and non-drought sediment yield and runoff.

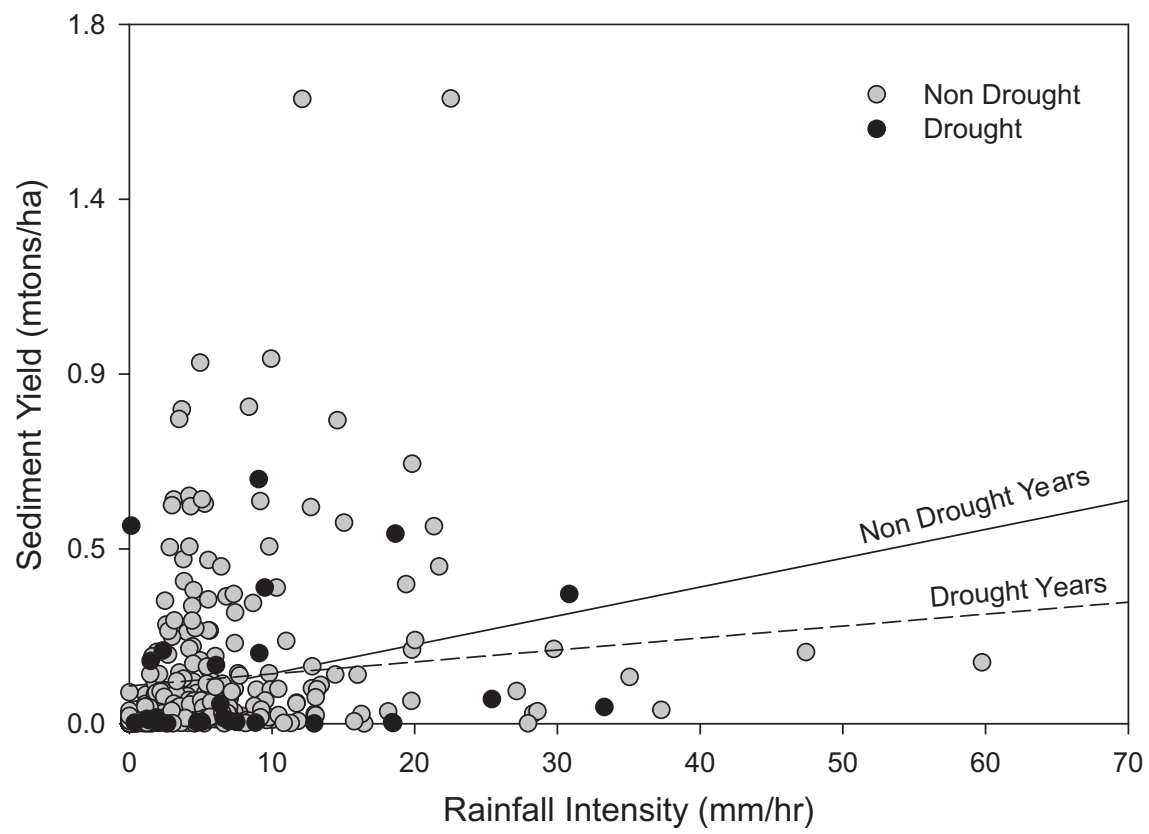

Fig. 9. Drought and non-drought sediment yield and rainfall intensity.

erodibility and allows greater sediment yield under runoff events (Smith et al., 1984). Since sediment erosion and transport are functions of these factors (runoff, soil state, and cover and slope), the data at Riesel demonstrate that high sediment yield from storm events during drought in the Blackland Prairie can be expected. As annual or effective precipitation increases, vegetative cover and soil structure are enhanced, which in turn require increased runoff and higher tractive forces to dislodge clay particles. The Riesel data also indicate that if the rainfall intensity and storm volumes are large enough, high sediment yields are also possible during non-drought periods (Fig. 8).
The very strong correlation $\left(R^{2}=0.97\right.$ based on linear and nonlinear regression) between sediment yield and runoff during the drought is similar to empirical equations of erosion by Kilinic (1972), Komura (1976), and more recently by Prosser and Rustomji (2000) and is typical of bare soil conditions. During non-drought periods (Fig. 8), sediment yield is poorly correlated with runoff due to influences of land use, land management, and related ground cover. Storms result in a highly scattered sediment yield response.

Nearing et al. (2005) investigated the response of seven erosion models to basic precipitation and vegetation parameters. Models 
ranged from empirically based models such as the Revised Universal Soil Loss Equation (RUSLE; Renard et al., 1993) to more physically and computationally intensive models as MEFIDIS (Numes et al., 2008). Nearing et al. (2005) notes that despite the variability in model structure, they all showed similar behavior under the different scenarios such as: (1) soil erosion is likely to be more affected than runoff by changes in rainfall and cover, (2) models were quite sensitive to rainfall intensity, even with the same rainfall volume, (3) models were more sensitive to changes in rainfall than to changes in cover, and (4) runoff and erosion changes more for each percent change in rainfall amount and intensity than to the same change in canopy and ground cover. The Riesel data support these model findings indicating that increased runoff with or without vegetative cover can produce substantial erosion and that the same amount of sediment can be generated with less runoff during drought periods. These findings imply that the use of erosion models for studying the complexity of climate change and sediment yield is supported by the Riesel data.

Heritage and Van Niekerk (1995) show that drought storm events generate greater sediment yield than similar magnitude events under typical conditions. This potential was also shown by Dunbar et al. (2010), as drought events produced $80 \%$ of the sediment in small upland floodwater structures. At Riesel the largest rain during the drought was a $\sim 2$ year frequency storm ( $24 \mathrm{~h}$ basis) according to Harmel et al. (2003) while in the western portion of the drought area, there were four major storm events (Dunbar et al., 2010). Drought sediment production at Riesel was only $9 \%$ of the total upland sediment production since 1945 . The major difference between the two studies is storm frequency and magnitude. Nearing et al. (2008) indicates that for semi arid watersheds at Walnut Gulch, Arizona, as few as $6-10$ events produced $50 \%$ of the sediment in six of the seven monitored watersheds; in the seventh watershed two storms produced $66 \%$ of the sediment. The differences in yield between the watersheds were attributed to differences in geology and vegetative cover. It appears that the number and duration of intense storms seems to be the critical variable in sediment yield for upland watersheds during dry periods.

\section{Conclusions}

The long-term record of rainfall, runoff, and erosion at Riesel made possible the present study of sediment yield from small upland watersheds during major droughts. The major conclusions from this study include: (1) drought sediment yield per unit runoff was at the upper threshold of all data for the watershed, and (2) the considerable scatter in long-term sediment-runoff relationships is attributed to the combined effects of changes in cover, soil erodibility, and rainfall volume and intensity. Annual sediment yield and runoff were reduced during the drought; however, sediment yield per unit of runoff was greater in the drought. Thus, with potentially drier conditions but with more intense storms in the changing climate (Pitlick, 1994, 1997), sediment yield could increase within the Texas Blackland Prairie (Pruski and Nearing, 2002) and in other semi-arid areas (Molnar, 2001; Nearing et al., 2008).

Soil erosion is influenced by complex interactions between plant cover, soil crusting and sealing, shifts in land use, plant biomass production, rainfall intensity and duration, and climatic trends (Nearing, 2001). These interactions vary by storm, season, and physiographic province and also by long-term trends in land use, management, and climate. Thus, field data collected through seasonal, annual, and even decadal cycles of climatic extremes are vital for adequate understanding and prediction of soil erosion and transport processes. The fact that drought period storms produced high rates of sediment per unit of runoff emphasizes the potential for very high rates of sediment production to occur, intense storms during periods of reduced vegetative cover. These results are alarming if rainfall amounts during the erodible times of the year were to increase as they did in the last Century in the US with rainfall increasing $10 \%$ and with more than $50 \%$ of that increase attributed to increased storm intensity (Nearing et al., 2005).

The Texas population is expected to rise from 21 million in 2000 to 46 million by 2060 (TWDB, 2007) with an expected increase in water demand of $27 \%$ (17-21.6 million acre feet) and a corresponding $18 \%$ decrease in reservoir storage capacity due to sedimentation. The need for long-term monitoring of processes in order to better assess the effectiveness of land management practices and predict the impacts on water supply is obvious. With an estimated recurrence interval of approximately one per century (Stahle and Cleaveland, 1988), the profound economic and environmental impact of severe droughts was marginally tolerable. With climate change, and the findings of this study, it appears that during periods of prolonged drought that the potential for very high rates of erosion are possible and perhaps predictable. Work by Dunbar et al. (2010) and Polyakov et al. (2010) reinforce this tenant in that one or two intense storms during a drought under conditions of reduced biomass can contribute the majority of sediment to local streams. With storm and runoff increasing under climate change, the need for offsetting management, enhanced modeling, and continued monitoring is justified.

\section{References}

Allen, P.M., Harmel, R.D., Arnold, J.G., Plant, B., Yeldermann, J., King, K.W., 2005. Field data and flow system response in clay (vertisol) shale terrain, north central Texas, USA. Hydrol. Process. 19 (14), 2719-2736.

Andreadis, K.M., Clark, E.A., Wood, A.W., Hamlet, A.F., Lettenmaier, D.P., 2005 Twentieth century drought in the coterminous United States. Am. Meteorol. J. 6, 985-1001.

Arnold, J.G., Potter, K.N., King, K.W., Allen, P.M., 2005. Estimation of soil cracking and the effect on surface runoff in a Texas Blackland Prairie watershed. Hydrol. Process. 19 (3), 589-603.

Baird, R.W., 1948. Runoff and soil conservation practices. Agric. Eng. 29 (5), 216 217.

Baird, R.W., 1950. Rates and Amounts of Runoff for the Blacklands of Texas. Tech. Bulletin No. 1022. Washington, DC, USDA.

Baird, R.W., 1964. Sediment yields from Blackland watersheds. Trans. ASAE 7 (4), 454-465.

Barlow, M., Nigam, S., Berbery, E.H., 2001. ENSO, Pacific decadal variabiity, and U.S. summertime precipitation, drought, and streamflow. J. Climate 14, 2105-2128.

Ben-Hur, M., Shainberg, I., Keren, R., Gal, M., 1985. Effect of water quality and drying on soil crust properties. Soil Sci. Soc. Am. J. 49, 191-196.

Bonta, J.V., 2004. Stochastic simulation of storm occurrence, depth, duration, and within-storm intensities. Trans. ASAE 47 (5), 1573-1584.

Bryan, R.B., 1996. Erosion response to variations in interstorm weathering conditions. In: Anderson, M.G., Brooks, S. (Eds.), Advances in Hillslope Processes, vol. 1. Wiley, Chichester, UK, pp. 589-612.

Bryan, R.B., 2000. Soil erodibility and processes of water erosion on hillslope. Geomorphology 32, 385-415.

Chichester, F.W., Richardson, C.W., 1992. Sediment and nutrient loss from clay soils as affected by tillage. J. Environ. Qual. 21 (4), 587-590.

Clark, J.S., Grimm, E.C., Donovan, J.J., Fritz, S.C., Engstrom, D.R., Almendinger, J.E. 2002. Drought cycles and landscape responses to past aridity on prairies of the northern great plains, USA. Ecology 83 (3), 595-601.

Coonrod, J.E., Holley, E.R., Maidment, D.R., Ward, G.H., 1998. Suspended Sediment Yield in Texas Watersheds. Center for Research in Water Resources, Bureau of Engineering Research, Technical Report CRWR 270. Univ of Texas, Austin TX.

Diodato, N., 2006. Modelling net erosion responses to enviroclimatic changes recorded upon multisecular timescales. Geomorphology 80, 164-177.

Dunbar, J.A., Allen, P.M., Bennett, S.J., 2010. Effect of multiyear drought on upland sediment yield and subsequent impacts on flood control reservoir storage. Water Resour. Res. 46, W05526, doi: 10.1029/2008WR007519.

Edwards, W.M., Owens, L.B., 1991. Large storm effects on total soil erosion. J. Soil Water Conserv, 46 (1), 75-78.

Freebairn, D.M., Loch, R.J., Silburn, D.M., 1996. Soil erosion and soil conservation for vertisols. In: Ahmad, N., Mermut, A. (Eds.), Vertisols and Technologies for Their Management: Developments in Soil Science No. 24. Elsevier, Netherlands.

Giakoumakis, S.G., Tsakiris, G.P., 1997. Meterological drought effect on sediment yield. Water Resour. Manage. 110, 365-376. 
Harmel, R.D., King, K.W., Richardson, C.W., Williams, J.R., 2003. Long-term precipitation analyses for the central Texas Blackland prairie. Trans. ASAE 46 (5), 1381-1388.

Harmel, R.D., Richardson, C.W., King, K.W., Allen, P.M., 2006. Runoff and soil loss relationships for the Texas Blackland Prairies ecoregion. J. Hydrol. 331 (3-4), 471-483.

Harmel, R.D., Bonta, J.V., Richardson, C.W., 2007. The original USDA-ARS experimental watersheds in Texas and Ohio: contributions from the past and visions for the future. Trans. ASABE 50 (5), 1669-1675.

Heppner, C.S., Loague, K., 2008. Characterizing long-term hydrologic response and sediment-transport for the R-5 catchment. J. Environ. Qual. 37 (6), 2181-2191.

Heritage, G.L., Van Niekerk, A.W., 1995. Drought conditions and sediment transport in the Sabie River. Koedoe: Afr. Protected Area Conserv. Sci. 38 (2), 1-9.

Hong, Y., Adler, R.F., Hossain, F., Curtis, S., Huffman, G.J., 2007. A first approach to global simulation using satellite rainfall estimation. Water Resour. Res. 43, W08502, doi: 10.1029/2006WR005739.

Imeson, A.C., Lavee, H., 1998. Soil erosion and climate change: the transect approach and the influence of scale. Geomorphology 23, 219-227.

Jaeger, K.L., Wohl, E., Simon, A., 2010. A comparison of average reates of alluvia erosion between the southwestern and south eastern United States. Earth Surf. Process. Land. 35, 447-459.

Kilinic, M.Y., 1972. Mechanics of Soil Erosion for Overland Flow Generated by Simulated Rainfall. PhD. Thesis Colorado State Univ., Fort. Collins, CO, USA

Knapen, A., Poesen, J., De Baets, S., 2007. Seasonal variations in soil erosion resistance during concentrated flow for a loess derived soil under two contrasting tillage practices. Soil Till. Res. 94, 425-440.

Kochel, R.C., Miller, J.R., Ritter, D.F., 1997. Geomorphic response to minor cyclic climate changes, San Diego County, California. Geomorphology 19, 277-302.

Kohler, M.A., Linsley, R.K., 1951. Predicting the Runoff from Storm Rainfall. Weather Bureau, US Department of Commerce, Research Paper, No. 34, Washington, DC, p. 9.

Komura, S., 1976. Hydraulics of slope erosion by overland flow. J. Hydraul. Div. ASCE 102 (10), 1573-1586.

Kuhn, N.J., Bryan, R.B., 2004. Drying, soil surface condition, and interrill erosion on two Ontario soils. Catena 57, 113-133.

Lane, L.L., Hernandez, M., Nichols, M., 1997. Processes controlling sediment yield from watersheds as functions of spatial scale. Environ. Model. Softw. 12 (4), 355-369.

Langbein, W.B., Schumm, S.A., 1958. Yield of sediment in relation to mean annual precipitation. Trans. Am. Geophys. Union 39, 1076-1084.

Lott, N., Ross, T., 2005. Tracking and Evaluating US Billion Dollar Weather Disasters, 1980-2005. NOAA National Climatic Data Center, Asheville, NC.

Lowry, R.L., 1959. A Study of Droughts in Texas. Bulletin 5914, Texas Board of Water Engineers, Austin, TX. 76p.

Martinez-Mena, M., Williams, A.G., Ternan, J.L., Fitzjohn, C., 1998. Role of antecedent soil water content on aggregates stability in a semi arid environment. Soil Till. Res. 48, 71-80.

Molnar, P., 2001. Climate change, flooding in arid environments, and erosion rates. Geology 29, 1071-1074.

National Climatic Data Center (NCDC), 2010. <http://lwf.ncdc.noaa.gov/temp-andprecip/time-series/index.php>.

Nearing, M.A., 2001. Potential changes in rainfall erosivity in the US with climate change during the 21st century. J. Soil Water Conserv. 56 (3), 229-232.

Nearing, M.A., Pruski, F.F., O'Neal, M.R., 2004. Expected climate change impacts on soil erosion rates: a review. J. Soil Water Conserv. 59 (1), 43-50.

Nearing, M.A., Jetten, V., Baffaut, C., Cerdan, O., Couturier, A., Hernandez, M., Le Bissonnais, Y., Nichols, M.H., Nunes, J.P., Renschler, C.S., Souchere, V., van Oost, K., 2005. Modeling response of soil erosion and runoff to changes in precipitation and cover. Catena 61, 131-154.

Nearing, M.A., Nichols, M.H., Stone, J.J., Renard, K.G., Simanton, J.R., 2008. Sediment yields from unit source semi arid watersheds at Walnut Gulch. Water Resour. Res. 43, WO6426, doi: 10.1029/2006WR005692.

Nichols, M.H., Renard, K.G., Osborn, H.B., 2002. Precipitation changes from 1956 to 1996 on the Walnut Gulch experimental watershed. J. Am. Water Resour. Assoc. 38 (1), 161-172.

Numes, J.P., Seixas, J., Pacheco, N.R., 2008. Vulnerability of water resources, vegetation productivity and soil erosion to climate change in Mediterranean watersheds. Hydrol. Process. 22, 3115-3134.
Pierson, F.B., Slaughter, C.W., Crane, Z.K., 2001. Long-term stream discharge and suspended sediment database, Reynolds Creek experimental watershed, Idaho, United States. Water Resour. Res. 37 (11), 2857-2861.

Pitlick, J., 1994. Relation between peak flows, precipitation, and physiography for five mountainous regions in the western USA. J. Hydrol. 158, 219-240.

Pitlick, J., 1997. A regional perspective of the hydrology of the 1993 Mississippi River Basin flood. Ann. Assoc. Am. Geogr. 87, 135-151.

Polyakov, V., Neaing, M.A., Nichols, M.H., Scott, R.L., Stone, J.J., Mcclaran, M., 2010. Long-term runoff and sediment yields from small semi-arid watersheds in southern Arizona. Water Resour. Res. 46, W09512. doi:10.1029/ 2009WR009001.

Prosser, I.P., Rustomji, P., 2000. Sediment transport capacity relations for overland flow. Prog. Phys. Geogr. 24, 179-193.

Prosser, I.P., Hughes, A.O., Rutherfurd, I.D., 2000. Bank erosion of an incised upland channel by subaerial processes: Tasmania, Australia. Earth Surf. Process. Land. 25, 1085-1101.

Pruski, F.F., Nearing, M.A., 2002. Runoff and soil loss response to changes in precipitation: a computer simulation study. J. Soil Water Conserv. 57 (1), 7-16.

Renard, K.G., Lane, L.J., Simanton, J.R., Emmerich, W.E., Stone, J.J., Weltz, M.A., Goodrich, D.C., Yakowitz, D.S., 1993. Agricultural impacts in an arid environment: Walnut Gulch studies. Hydrolog. Sci. Tech. 9, 145-190.

Richardson, C.W., King, K.W., 1995. Erosion and nutrient losses from zero tillage on a clay soil. J. Agric. Eng. Res. 61 (2), 81-86.

Ruiz-Sinoga, J.D., Martinez-Murillo, J.F., 2009. Eco-geomorphological system response variability to the 2004-2006 drought along a climatic gradient of the Littoral Beltic Range, southern Spain. Geomorphology 103, 351-362.

Seager, R., 2007. The turn of the century North American drought: Global context, dynamics, and past analogs. J. Climate 20, 5527-5552.

Simon, A., Dickerson, W., Heins, A., 2004. Suspended sediment transport rates at the 1.5 year recurrence interval for ecoregions of the United States: transport conditions at the bankfull and effective discharge? Geomorphology 58, 243262.

Slaughter, C.W., Richardson, C.W., 2000. Long-term watershed research in USDA Agricultural Research Service. Water Resour. IMPACT 2 (4), 28-31.

Smith, R.M., Henderson, R.C., Tippit O.J., 1954. Summary of Soil and Water Conservation Research from the Blackland Experimental Station, Temple, Texas, 1942-1953. Texas Agricultural Experiment Station Bulletin 781, College Station, TX.

Smith, S.J., Williams, J.R., Menzel, R.G., Coleman, G.A., 1984. Prediction of sediment yield from southern plains grasslands with the modified universal soil loss equation. J. Range Manage. 37, 295-297.

Stahle, D.W., Cleaveland, M.K., 1988. Texas drought history reconstructed and analyzed from 1698-1980. J. Climate 1, 59-74.

Stahle, D.W., Fye, F.K., Cook, E.R., Griffin, R.D., 2007. Tree ring reconstructed megadroughts over North America since AD 1300. Clim. Change 83, 133-149.

Tallaksen, L.M., Hisdal, H., Van Lanen, H.A.J., 2009. Space time modeling of catchment drought characteristics. J. Hydrol. 375, 363-372.

Trimble, S.W., Crosson, P., 2000. US soil erosion rates - myth and reality. Science 289, 248-250.

Texas Water Development Board (TWDB), 2007. Water for Texas, Volume 1. Texas Water Development Board, Austin, TX.

Ward, P.J., Balen, R.T., Verstraeten, G., Renssen, H., Vandenberghe, J., 2009. The impact of land use and climate change on Late Holocene and future suspended sediment yield of the Meuse catchment. Geomorphology 103, 389-400.

Wilson, L., 1973. Sediment yield as a function of climate in the United States rivers. In: Rodda, J.C. (Ed.) Erosion and Solid Matter Transport in Inland Waters. Sci. Publ. 122. Proceedings of the Paris Symposium, July 1977. International Association of Hydrological Sciences, Washington, DC, pp. 34-38.

Wischmeier, W.H., Smith, D.D., 1965. Predicting Rainfall-erosion Losses from Cropland East of the Rocky Mountains: Guide for Selection of Practices for Soil and Water Conservation, Agriculture Handbook No. 282, USDA-ARS, Washington, DC

Wolman, M.G., Gerson, R., 1978. Relative scales of time and effectiveness of climate in watershed geomorphology. Earth Surf. Process. Land. 3, 189-208.

Woodhouse, C.A., Overpeck, J.T., 1998. 2000 years of drought variability in the central United States. Bull. Am. Meterol. Soc. 79 (12), 2693-2714.

Zhang, X.C., Miller, W.P., 1993. The effect of drying on runoff and interrill erosion of crusted soils. Catena Suppl. 24, 103-114. 